\title{
Effect of Entrepreneurial Education on Unemployment Reduction among Students in Nigeria
}

\author{
Jacobs, Chineze J. ${ }^{1}$, Ezeokafor, Uche R. ${ }^{1}$ \& Ekwere Gabriel E. ${ }^{2}$ \\ ${ }^{1}$ Department of Entrepreneurship Studies, Chukwuemeka Odumegwu Ojukwu University, Igbariam Anambra State, \\ Nigeria \\ ${ }^{2}$ Department of Cooperative Economics and Management, Nnamdi Azikiwe University, Awka. Anambra State. \\ Nigeria \\ Correspondence: Ekwere Gabriel E., Department of Cooperative Economics and Management, Nnamdi Azikiwe \\ University, Awka, Anambra State, Nigeria.
}

Received: April 21, 2021

Accepted: June 23, 2021

Online Published: June 30, 2021

doi:10.5430/bmr.v10n2p16

URL: https://doi.org/10.5430/bmr.v10n2p16

\begin{abstract}
The study examined the effect of entrepreneurial education on unemployment reduction among students in Chukwuemeka Odumegwu Ojukwu University, Igbaria. The problem of the study is as a result of increasing rate of unemployment in Nigeria. The study was anchored on Human Capital Theory and risk taking theory. As a cross-sectional survey research design, a structured instrument developed by the researcher to reflect such options as strongly agree, agree, undecided, disagree and strongly disagree popularly referred to as five (5) points likert scale was used to obtain information from the respondents. The population of the study was limited to final year students of Business Administration and Entrepreneurship Studies Department in Chukwuemeka Odumegwu Ojukwu University, Igbariam. The total population was 195 . Business administration was 128 while entrepreneurship was 67 . The study used convenience sampling technique in selecting the sample size for the study based on convenience and easy accessibility to the respondents. Research hypotheses were tested using Multiple Regression Analysis (MRA) which was carried out with the aid of Statistical Package for Social Science (SPSS). Findings from the study revealed that Skill acquisition has significant effect on unemployment reduction, Entrepreneurship empowerment affects unemployment reduction, Infrastructural development has significant effect on unemployment reduction in Anambra State. The study recommended that Entrepreneurial education in tertiary institutions should be practical oriented rather than theory as this will exposed the students to various lucrative skills. Government should provide a means of getting loans by small scale business owners in order to enhance the activities of small scale business in Nigeria.
\end{abstract}

Keywords: entrepreneurial education, unemployment reduction, human capital theory, risk taking theory, infrastructural development, entrepreneurship empowerment

\section{Introduction}

In Nigeria today, education and training is beginning to take a new aspect as many people are diving, driving and embracing education in its totality. This singular act of being educated has resulted to enormous number of graduates from various universities, polytechnics, colleges of education etc. The perceptions of earning a living with university (tertiary institutions) certificate after graduation has endangered Nigerian system of education and have also generate an increase in the number of unemployed graduates. In fact, unemployment is an epidemic economic issue whose social implications affect almost every country of the world and her citizens either directly or indirectly.

Olubukola (2013) asserted that unemployment is a global happening where suitable workforce of a nation is disengaged in the overhaul of the nation while World Bank (2009) defines unemployment as the share of the labour force that is without work but available for and seeking employment. In order to reduce the rate of unemployment among Nigerian number of graduates roaming about on the street with certificate qualification without having a meaningful source of livelihood, the concept of entrepreneurial education (training) was introduce into tertiary education in Nigeria.

The aim of entrepreneurial education was for knowledge acquisition by students to enable them setting up and hovering a business with other skills needed for its survival and also to become successful entrepreneurs. Maina (2013) 
sees entrepreneurial education as part of the total educational system that involves the acquisition of skills, ideas and management abilities necessary for job creation.

For Gibson (2001), entrepreneurial education is defined as the process of using private initiative to transform a business concept into a new venture or to grow and diversify an existing venture or enterprise with high great potential. Entrepreneurial education is a lifelong process, starting as early as the elementary school and progressing through all levels of education, including adult education. It is seen as a tool which equips an individual to be an entrepreneur (Antoncic \& Hisrich, 2003).

The rate of unemployment among Nigerian graduates is a threat to the nation's economy as tertiary institutions produces graduates yearly without commensurate job opportunities. Ekpo (2010) succinctly stated that a study carried out by the Federal Ministry of Education from 2005-2010 showed that seventy one percent (71\%) of graduate students from Nigerian Universities and other forms of tertiary institutions are yet to get job. In similar development, Nwachukwu (2012) reported that Economic Survey in 2011 doted unemployment rate in Nigeria at 23.9\%. In other words, over 38 million Nigerians are unemployed. It is disturbing to acknowledge that a greater number of this percentage are graduates from Nigeria universities, colleges of education and polytechnics who roam the street and in the job markets looking for non existing jobs for lack of entrepreneurial skills. Lack of entrepreneurial skills is no doubt a major contributing factor to the problem of unemployment of graduates in Nigeria (Adebisi \& Oni, 2012). The incidence of graduate unemployment is attributed to the educational system operated during pre and post independence era in the country which placed emphasis on liberal education rather than acquisition of vocational skills which prepares school leavers and graduates with vocational skills for better employment opportunities.

Again, in spite of federal government efforts to create 2 million jobs every year, most Nigerian university graduates fail to get employed (Babalola, 2007). This is evident as many graduates stay 3-4 or more years after graduation before getting a job or no job at all. Based on these pathetic situations, it interests the researchers' to investigate the role of entrepreneurial education in the reduction of unemployment rate among Nigerian graduates.

\subsection{Objective of the Study}

The broad objective of this study was to examine the effect of entrepreneurial education in the reduction of unemployment among Nigerian graduates. Specific objectives were to:

i. Determine the effect of skill acquisition on unemployment reduction in Nigeria.

ii. Ascertain the effect of entrepreneurship empowerment in reducing unemployment in Nigeria.

iii. Investigate the effect of infrastructural development in reducing unemployment in Nigeria.

\section{Review of Related Literature}

\subsection{Theoretical Framework}

\subsubsection{The Human Capital Theory}

The theoretical structure of this study anchored on human capital theory (HCT) propounded by Schultz 1979. The theory advocates education as a tool of improving human capital, stimulating labour productivity and boosting the level of technology across the globe (Robert 1991). Human capital theorist encourage spending on nations workforce (people working with public and private sector organization) because expenditure on training and development is a productive investment like investment on physical assets (Olaniyan \& Okemakinde 2008). Besides, human capital enhancement through quality education is a critical factor that propels economic growth and sustainable development in East Africa, Hong Kong, Korea, Singapore and Taiwan. Schumpeter (1934) views entrepreneurship training as responsible for creative destruction, that is, education act as an impetus for creating new ideas improved techniques, new technologies and new products. In addition, Van-Den-Berg (2001) established in correlation between the level of education and new product development in knowledge based economies that invested massively in education, technology and related elements.

\subsubsection{Risk Taking Theory (RRT)}

Another theory that supports entrepreneurship education is the Risk Taking Theory of Rchard Cantillon and John Stuart Mill. The theory perceives entrepreneurship as a mental education that stimulates individual to take calculated risk for future streams of benefits are guaranteed, and people taking big risk have to contend with a great responsibility (Aham \& Hossan, 2003). The summary of the theory is that entrepreneurship education improves the ability, capability and potentials of individuals to undertake risk for which economic benefits are assured. 


\subsection{Empirical Review}

Prior studies on entrepreneurship education in reducing unemployment among scholars presented perspective and findings.

Agu, Anidiobu and Ezinwa (2016), Entrepreneurship Education: A Panacea for unemployment in Nigeria. This study focused on entrepreneurship education as a panacea for unemployment in Nigeria. A descriptive survey research method was adopted. Stratified random sampling method was used to select 120 entrepreneurs and 80 scholars from Enugu State. The instrument of data collection for this study was questionnaire administered to respondents. Ten (I0) questionnaire items that measured entrepreneurship education as a panacea to unemployment in Enugu State was presented. The techniques of analyses adopted included the statistical weighted means, scores and standard deviation. Findings arising from the study revealed that the increasing global phenomenon and awareness on entrepreneurship education will enhance the acquisition of the necessary skills for gainful and self- employment. The Nigerian educational policy should further consider the introduction of entrepreneurship development programme as a compulsory course in all level of our educational system in Nigeria. Attention should be given to the appropriate entrepreneurial education to encourage the emergence of individuals with required entrepreneurial skills so as to reduce the high level unemployment in Nigeria.

Ezeanokwasa and Nwachukwu (2014), examined the effective entrepreneurship skills in reducing unemployment through small business innovation in Nigeria. The research design used for this research work was descriptive research design. The questionnaire was the instrument distributed to the participants. Frequencies, arithmetic means, standard deviations and t-statistics was used to analyze the data. The findings of the study showed that the contribution of entrepreneurship skills towards reducing unemployment in Nigeria include Improvement in the standard of living through innovation that led to introduction of high goods and services and conservation of foreign exchange as a result from reduced importation of machines and equipment, raw material and payment to foreign export. It was found also that there is significant relationship exists between effective entrepreneurial skills and unemployment in Nigeria. Base on the findings the following recommendations were made that multiple taxations system such as personal income tax, company tax, stamp duties and Valued Added Tax [VAT] should be control by the government and provision of infrastructure like stable electricity, good roads, free movement of production goods should be adequately improved in the country.

Tambari and Popnwin (2017), examines the role of entrepreneurial education in the reduction of unemployment among Nigerian graduates. The population of the study comprises of 732 corps members in Rivers State. A sample of 548 corps members were composed and used for the study through purposive sampling technique. Three research questions were formulated to guide the study. The instrument used for data collection was questionnaire titled "Reducing Unemployment among Nigerian Graduates through Entrepreneurial Education" (RUNGEE) which was design using Likert - 5- point rating scale. The RUNGEEQ was specifically used to obtained information base on the research questions. The research questions were answered using mean with standard deviation. It was found that Skills such as welding and fabrication, food and catering services, electrical installation etc can make Nigerian graduates entrepreneurs to reduce unemployment. Creation of jobs for self-employment, stimulation of rural, economic and industrial development are benefits of entrepreneurial education to Nigerian graduates. Based on the findings, it was recommended among others that Entrepreneurial education in tertiary institutions should be practically oriented rather than theory as this will exposed the students to various lucrative skills, Access to credits/loans should be granted without collateral in order to make the training realizable and achievable

Asogwa, and Dim (2016), investigates the relationship between Entrepreneurship education and employment reduction in Anambra State, Nigeria. The research focused on youths of five selected Local Government Council of Anambra state, Nigeria. Data were collected using questionnaire from an infinite population of the selected Local Government Council. Samples of 30 youths were drawn from the population of each Local Government through a convenience sampling technique. A total of 150 youths were sample for the study. However, four hypotheses were tested; the first, second and third hypotheses were designed to investigate the relationship between Entrepreneurship training and unemployment reduction; the relationship between Entrepreneurship traits and unemployment reduction; and the relationship between Entrepreneurship empowerment and unemployment reduction respectively. The fourth hypothesis was on the examination of entrepreneurship challenges affecting unemployment reduction. The test conducted shows that the variables in the first three hypotheses were significantly and positively related and fourth hypothesis was also significant. The study recommended that Government should strive to reduce the cost of doing business in Nigeria. Unemployed youths in Anambra State should also be strengthened to embrace entrepreneurship devoid the imitation and vocational inclinations. 
Muogbo and John-Akamelu (2018), examined the impact of entrepreneurial skill in reducing youth unemployment in Nigeria with reference to ABC Transport Company in Anambra State. The broad objectives of this study is to examine the possibly ways of eradicating unemployment through the introduction of entrepreneurial skills. The study is a descriptive survey design. Questionnaire items were distributed to 160 respondents to gather factual information about the topic. Their responses were tested using appropriate statistic tools like the simple percentage and the chi-square method. The study found that there are roles entrepreneurial skills and businesses play in youth employment in Nigeria through entrepreneurial development. Furthermore, it also shows that youths in Anambra state can be given basic training on how best to establish and grow business enterprise in local communities within the state. The study therefore recommends that government should remove corruption and greed and formulate policies that will promote the success of entrepreneurship and free enterprise; government should assist entrepreneurs through regular marketing workshops and seminars in conjunction with the manufacturers association of Nigeria (MAN) and chambers of commerce and industries.

\section{Methodlogy}

This study however adopted the survey research design. The survey research design method was used in this study, by collecting data through questionnaire from population of interest. It involved using a self-designed questionnaire in collecting data from the respondents.

Population is a set of objects or observations about which conclusions will be drawn. The ideal population for this study would have been the entire students. However, for more accuracy and effectiveness, the study population is limited final students of Business administration and Entrepreneurship studies department in Chukwuemeka Odumegwu Ojukwu University, Igbariam. The total population is 195 . Business administration is 128 while entrepreneurship is 67 . The study used convenience sampling technique in selecting the sample size of the study based on convenience and easy accessibility to the respondents.

Research instruments are those tools which are being used to collect data for the purpose of testing hypothesis and answering research questions (Ojo, 2015). To enable the collection of data and analysis, the researcher needs various types of instrument specifically designed for multi various purpose. The selection of instrument depended on such factors as the nature of the study. The research instrument for this study was the questionnaire. Inferential statistics was used to reach conclusions and make generalizations about the characteristics of populations based on data collected from the sample. Descriptive statistics was used to analyze the demographical data. Hypotheses were analyzed using correlation coefficient at $0.05 \%$ level of significance. The correlation coefficient is an approach employed in establishing the relationship between the dependent variable and one or more explanatory variables examining the relationship between two.

\section{Data Analysis and Data Presentation}

Data were collated, presented and analyzed in order to proffer answers to research questions. The responses from students of Chukwuemeka Odumegbu Oukwu University (COOU), Igbariam Campus effectively address the problem of concern.

\subsection{Presentation of Data}

After the administration and collection of instrument from the two hundred (200) copies of questionnaire to the students of the selected universities in COOU, one hundred and ninety five (195) were properly filled and returned, thus making the response rate to be $97.5 \%$. Below are the data presented in frequency table.

The results of Table 1 shows that majority of the respondents are male (54.5\%). Most students are those whose age bracket falls between 26-30 years and above 31years respectively. And the major of the students are in 100 levels. The data presented indicates that majority of the students are matured enough know the variables under investigation. They have acquired some educational qualification even before they are admitted into their respective universities. So, it is believed that they should be sensitive enough to know what entrepreneurial education is about. 
Table 1. Distribution of respondents based on their bio-data

\begin{tabular}{|c|c|c|c|}
\hline $\mathbf{S} / \mathbf{N}$ & Variables & Frequency & Percentage \\
\hline \multirow{4}{*}{1} & Gender & & \\
\hline & Male & 110 & 54.5 \\
\hline & Female & 85 & 45.5 \\
\hline & Total & 195 & 100 \\
\hline \multirow{5}{*}{2} & Age & & \\
\hline & 21-25 years & 23 & 9.8 \\
\hline & 26-30 years & 135 & 57.4 \\
\hline & 31 years and above & 37 & 32.8 \\
\hline & Total & 195 & 100 \\
\hline \multirow{6}{*}{3} & Levels & & \\
\hline & 100 & 102 & 43.4 \\
\hline & 200 & 66 & 28.1 \\
\hline & 300 & 15 & 22.5 \\
\hline & 400 & 12 & 6.0 \\
\hline & Total & 195 & 100 \\
\hline
\end{tabular}

Source: Field Survey, 2021.

\subsection{The Extent to Which Skill Acquisition Affected Unemployment Reduction in Anambra State}

Research Question 1: To what extent has skill acquisition affected unemployment reduction in Anambra State.

The remarks as shown in Table 2 indicated that the overall decision of the respondents on each of the question items (row) in the table. Students desire to participate in entrepreneurship activities in higher institution. Again, the respondents believed Goal and objectives of Entrepreneurship Education will make one self-reliant and productivity. Majority of the students also believed that Entrepreneurship Education is the key to economic empowerment among undergraduate in Anambra State. The students also believed that Parental negative attitude towards technical and vocational Education (TVE) has given room for development of Entrepreneurship education among undergraduate.

Table 2. Analysis on skill acquisition and its effect on unemployment reduction

\begin{tabular}{|c|c|c|c|c|c|c|c|}
\hline SN & Variable & SA & $\mathbf{A}$ & I & D & SD & Remarks \\
\hline 1 & $\begin{array}{l}\text { Students love to participate in } \\
\text { entrepreneurship activities in higher } \\
\text { institution }\end{array}$ & $\begin{array}{l}138 \\
(58.7 \%)\end{array}$ & $\begin{array}{l}35 \\
(38.7 \%)\end{array}$ & $\begin{array}{l}22 \\
(6.0 \%)\end{array}$ & - & - & Agreement \\
\hline 2 & $\begin{array}{l}\text { Goal and objectives of Entrepreneurship } \\
\text { Education will make only one self reliant } \\
\text { and productivity }\end{array}$ & $\begin{array}{l}145 \\
(61.7 \%)\end{array}$ & $\begin{array}{l}50 \\
(38.3 \%)\end{array}$ & - & - & - & Agreement \\
\hline 3 & $\begin{array}{l}\text { Entrepreneurship Education is the key to } \\
\text { economic empowerment among } \\
\text { undergraduate in Anambra state. }\end{array}$ & $\begin{array}{l}40 \\
(36.2 \%)\end{array}$ & $\begin{array}{l}115 \\
(48.9 \%)\end{array}$ & $\begin{array}{l}20 \\
(2.6 \%)\end{array}$ & $\begin{array}{l}15 \\
(10.6 \%)\end{array}$ & $\begin{array}{l}5 \\
(1.7 \%)\end{array}$ & Agreement \\
\hline 4 & $\begin{array}{l}\text { Parental negative attitude toward } \\
\text { technical and vocational Education } \\
\text { (TVE) has given room for development } \\
\text { of Entrepreneurship education among } \\
\text { undergraduate }\end{array}$ & $\begin{array}{l}110 \\
(57.9 \%)\end{array}$ & $\begin{array}{l}61 \\
(32.8 \%)\end{array}$ & $\begin{array}{l}10 \\
(3.8 \%)\end{array}$ & $\begin{array}{l}9 \\
(3.4 \%)\end{array}$ & $\begin{array}{l}5 \\
(2.1 \%)\end{array}$ & Agreement \\
\hline
\end{tabular}

Source: Field Survey, 2021. 


\subsection{The Degree at Which Entrepreneurial Empowerment Affected Unemployment Reduction in Anambra State}

Research Question 2: To what degree has entrepreneurial empowerment affected unemployment reduction in Anambra state?

The results of Table 3 revealed that students are of the view that Entrepreneurship Education is that tendency of equipping and making students experts in the production of economic goods. The study made it clear that Role of entrepreneurship Education will go a long way of equipping and making students experts in the production of certain items. In addition, it is obvious that Entrepreneurship education can greatly help in addressing the level of poverty among undergraduate through employable job. Furthermore, the respondents believed that Entrepreneurship Education involves a systematic search for an analysis of opportunities.

Table 3. Analysis on the entrepreneurial empowerment and its effect on unemployment reduction

\begin{tabular}{|c|c|c|c|c|c|c|c|}
\hline SN & Variable & $\mathbf{S A}$ & $\mathbf{A}$ & I & D & SD & Remarks \\
\hline 5 & $\begin{array}{l}\text { Entrepreneurship Education is that tendency of equipping } \\
\text { and making students experts in the production of certain } \\
\text { items }\end{array}$ & $\begin{array}{l}126 \\
(53.6 \%)\end{array}$ & $\begin{array}{l}50 \\
(41.3 \%)\end{array}$ & $\begin{array}{l}19 \\
(5.1 \%)\end{array}$ & - & - & Agreement \\
\hline 6 & $\begin{array}{l}\text { Role of entrepreneurship Education is that tendency of } \\
\text { equipping and making students experts in the production } \\
\text { of certain items }\end{array}$ & $\begin{array}{l}109 \\
(63.4 \%)\end{array}$ & $\begin{array}{l}74 \\
(31.5 \%)\end{array}$ & $\begin{array}{l}12 \\
(5.1 \%)\end{array}$ & - & - & Agreement \\
\hline 7 & $\begin{array}{l}\text { Entrepreneurship education can greatly help in addressing } \\
\text { the level of poverty among undergraduate through } \\
\text { employable job }\end{array}$ & $\begin{array}{l}90 \\
(54.5 \%)\end{array}$ & $\begin{array}{l}70 \\
(34.9 \%)\end{array}$ & $\begin{array}{l}25 \\
(6.4 \%)\end{array}$ & $\begin{array}{l}10 \\
(4.3 \%)\end{array}$ & & Agreement \\
\hline 8 & $\begin{array}{l}\text { Entrepreneurship Education involves a systematic search } \\
\text { for an analysis of opportunities. }\end{array}$ & $\begin{array}{l}95 \\
(57.9 \%)\end{array}$ & $\begin{array}{l}91 \\
(38.7 \%)\end{array}$ & $\begin{array}{l}9 \\
(3.8 \%)\end{array}$ & - & - & Agreement \\
\hline
\end{tabular}

Source: Source: Field Survey, 2021.

\subsection{The Extent to Which Infrastructural Development Has Affected Unemployment in Anambra State}

Research Question 3: To what extent has infrastructural development affected unemployment in Anambra state?

The respondents had are of the opinion that Government should not be lukewarm towards Entrepreneurship Education. The above table also revealed that Lack of personnel, Equipment and material is problem associated to student attitudes toward Entrepreneurship Education. Again, the study shows that If Nigeria will achieve the millenniums development goals (MDGs) in 2020 then entrepreneurship Education is the key. Also, the students believed that the easy way to reduce unemployment among graduates is the teaching and learning of Entrepreneurship Education in school.

Table 4. Analysis on infrastructural development and its effect on unemployment reduction

\begin{tabular}{|c|c|c|c|c|c|c|c|}
\hline SN & Variable & SA & $\mathbf{A}$ & I & D & SD & Remarks \\
\hline 9 & $\begin{array}{l}\text { Government should not be lukewarm towards } \\
\text { Entrepreneurship Education }\end{array}$ & $\begin{array}{l}161 \\
(68.5 \%)\end{array}$ & $\begin{array}{l}26 \\
(11.1 \%)\end{array}$ & $\begin{array}{l}12 \\
(5.1 \%)\end{array}$ & $\begin{array}{l}28 \\
(11.9 \%)\end{array}$ & $\begin{array}{l}8 \\
(3.4 \%)\end{array}$ & Agreement \\
\hline 10 & $\begin{array}{l}\text { Lack of personnel, Equipment and material is problem } \\
\text { associated to student attitudes toward } \\
\text { Entrepreneurship Education }\end{array}$ & $\begin{array}{l}127 \\
(54 \%)\end{array}$ & $\begin{array}{l}96 \\
(40.9 \%)\end{array}$ & $\begin{array}{l}12 \\
(5.1 \%)\end{array}$ & - & - & Agreement \\
\hline 11 & $\begin{array}{l}\text { If Nigeria will achieve the millenniums development } \\
\text { goals (MDGs) in } 2020 \text { then entrepreneurship } \\
\text { Education is the key }\end{array}$ & $\begin{array}{l}142 \\
(60.4 \%)\end{array}$ & $\begin{array}{l}72 \\
(30.6 \%)\end{array}$ & $\begin{array}{l}21 \\
(8.9 \%)\end{array}$ & - & - & Agreement \\
\hline 12 & $\begin{array}{l}\text { The easy way to reduce unemployment among } \\
\text { graduates is the teaching and learning of } \\
\text { Entrepreneurship Education in school }\end{array}$ & $\begin{array}{l}85 \\
(36.2 \%)\end{array}$ & $\begin{array}{l}62 \\
(26.4 \%)\end{array}$ & $\begin{array}{l}11 \\
(4.7 \%)\end{array}$ & $\begin{array}{l}40 \\
(17.0 \%)\end{array}$ & $\begin{array}{l}37 \\
(15.7 \%)\end{array}$ & Agreement \\
\hline
\end{tabular}

Source: Field Survey, 2021. 


\subsection{Test of Hypotheses}

Regression analysis was used to test the formulated hypothesis. The results of the hypotheses test were interpreted accordingly;

\section{$\mathrm{Ho}_{1}$ : Skill acquisition has no significant effect on unemployment reduction.}

The model summary of Table 5 revealed the $\mathrm{R}$ to be at .259, $\mathrm{R}$ square at .211, adjusted $\mathrm{R}$ square at .303 while std error of the estimate at 3.67231. The table reveal that the $\mathrm{R}$ square being at .211 does not strongly determine the extent to which the independent variable affects the dependent variable.

Table 5a. Skill acquisition has no significant effect on unemployment reduction

\begin{tabular}{lllll}
\hline Model Summary & & & \\
\hline Model & $\mathrm{R}$ & R Square & Adjusted R Square & Std. Error of the Estimate \\
\hline 1 & $.259^{\mathrm{a}}$ & .211 & .303 & 3.67231 \\
\hline
\end{tabular}

a. Predictors: (Constant), skill acquisition.

Source: Field Survey, 2021.

The Anova table above show that the $\mathrm{F}$ value is at 34.871 and the significant level is at .000 which is lesser than .05 , that is the probability level. This signifies that there is significant factors that skill acquisition has significant effects on unemployment reduction in Anambra State. The null hypothesis is rejected.

Table 5b. ANOVA

\begin{tabular}{lllllll}
\hline Model & & Sum of Squares & Df & Mean Square & F & Sig. \\
\hline \multirow{2}{*}{1} & Regression & 177.612 & 1 & 177.612 & 34.871 & $.000^{\mathrm{b}}$ \\
\cline { 2 - 7 } & Residual & 664.135 & 194 & 7.141 & & \\
\cline { 2 - 7 } & Total & 841.747 & 195 & & & \\
\hline
\end{tabular}

a. Dependent Variable: unemployment reduction.

b. Predictors: (Constant), skill acquisition.

Source: Field Survey, 2021.

The coefficient table below shows the significant level of $t$ statistics which reveals that the $t$ value is at 4.987 and the sig. level at .000. This means that there is significant level of the independent variable on the dependent variable.

Table 5c. Coefficient

\begin{tabular}{|c|c|c|c|c|c|c|}
\hline \multicolumn{7}{|c|}{ Coefficients $^{\mathrm{a}}$} \\
\hline \multirow[t]{2}{*}{ Model } & & \multicolumn{2}{|c|}{ Unstandardized Coefficients } & Standardized & \multirow[t]{2}{*}{$\mathrm{t}$} & \multirow[t]{2}{*}{ Sig. } \\
\hline & & B & Std. Error & Beta & & \\
\hline \multirow{2}{*}{1} & (Constant) & 5.296 & .926 & & 7.721 & .000 \\
\hline & factor that hinder & .531 & .106 & .459 & 5.987 & .000 \\
\hline
\end{tabular}

Dependent Variable: Unemployment reduction.

Source: Field Survey, 2021. 


\section{$\mathrm{H}_{2}$ : Entrepreneurship empowerment does not affect reduction of unemployment}

The Table 4.6a below revealed that the $\mathrm{R}$ is at .062 , $\mathrm{R}$ square is at .004, Adjusted $\mathrm{R}$ square at -007 while std. error of the estimate at 5.00447. This shows that the R square being at .004 does not have a strong determinant of the independent variable over dependent variable.

Table 6a. Model Summary

\begin{tabular}{lllll}
\hline \multicolumn{2}{l}{ Model Summary } & & \\
\hline Model & $\mathrm{R}$ & R Square & Adjusted R Square & Std. Error of the Estimate \\
\hline 1 & $.062^{\mathrm{a}}$ & .004 & -.007 & 5.00447 \\
\hline
\end{tabular}

a. Predictors: (Constant), entrepreneurship empowerment.

Source: Field Survey, 2021.

The ANOVA table below shows that the F statistics at 4.549 and the significant level at .000 which is lesser than the probability of .05 . This therefore means that entrepreneurial empowerment affects reduction of unemployment in Anambra state. The null hypothesis is rejected.

Table 6b. ANOVA

\begin{tabular}{lllllll}
\hline ANOVA $^{\mathrm{a}}$ & \multicolumn{1}{l}{} & & & \\
\hline Model & & Sum of Squares & Df & Mean Square & F & Sig. \\
\hline \multirow{2}{*}{1} & Regression & 2.252 & 1 & 2.252 & 4.549 & $.000^{\mathrm{b}}$ \\
\cline { 2 - 7 } & Residual & 839.495 & 194 & 9.027 & & \\
\cline { 2 - 7 } & Total & 841.747 & 195 & &
\end{tabular}

a. Dependent Variable: unemployment reduction

b. Predictors: (Constant), entrepreneurship empowerment.

Source: Field Survey, 2021.

The coefficient table below shows that the $\mathrm{t}$ value is at 8.209 and sig. value is at .000 which signifies that there is significant of the independent variable over the dependent variable.

Table 6c. Cooefficient

\begin{tabular}{|c|c|c|c|c|c|c|}
\hline \multicolumn{7}{|c|}{ Coefficients $^{\mathrm{a}}$} \\
\hline \multirow[t]{2}{*}{ Model } & & \multicolumn{2}{|c|}{ Unstandardized Coefficients } & $\begin{array}{l}\text { Standardized } \\
\text { Coefficients }\end{array}$ & \multirow[t]{2}{*}{$\mathrm{t}$} & \multirow{2}{*}{ Sig. } \\
\hline & & $\mathrm{B}$ & Std. Error & Beta & & \\
\hline \multirow{2}{*}{1} & (Constant) & 10.314 & 1.256 & & 8.209 & .000 \\
\hline & farctor that enhance & -.065 & .129 & -.052 & -.499 & .619 \\
\hline
\end{tabular}

a. Dependent Variable: small business growth and survival.

Source: Field Survey, 2021.

\section{$\mathrm{H}_{3}$ : Infrastructural development has no significant effect on unemployment reduction in Anambra state.}

Table $4.7 \mathrm{a}$ revealed that the $\mathrm{R}$ at .034 , $\mathrm{R}$ square at .001 , adjusted $\mathrm{R}$ square at -.010 , while std error of the estimate at 3.00680. This reveals that $\mathrm{R}$ square being at .001 is not a good determinant of the strength of the independent variable over the dependent variable. 
Table 7a. Model Summary

\begin{tabular}{|c|c|c|c|c|}
\hline \multicolumn{5}{|c|}{ Model Summary } \\
\hline Model & $\mathrm{R}$ & R Square & Adjusted R Square & Std. Error of the Estimate \\
\hline 1 & $.034^{\mathrm{a}}$ & .001 & -.010 & 3.00680 \\
\hline
\end{tabular}

a. Predictors: (Constant), infrastructural development.

Source: Field Survey, 2021.

The ANOVA table below shows that the f value is at 4.105 and the sig is at .000 which is lesser than the probability level of .05. This means that infrastructural development has significant effect on unemployment reduction in Anambra State. Null hypothesis is rejected

Table 7b. ANOVA

\begin{tabular}{lllllll}
\hline ANOVA $^{\mathrm{a}}$ & \multicolumn{1}{l}{} \\
\hline Model & & Sum of Squares & Df & Mean Square & F & Sig. \\
\hline \multirow{2}{*}{1} & Regression & .950 & 1 & .950 & 4.105 & $.000^{\mathrm{b}}$ \\
\cline { 2 - 7 } & Residual & 840.798 & 93 & 9.041 & & \\
\cline { 2 - 7 } & Total & 841.747 & 94 & & & \\
\hline
\end{tabular}

a. Dependent Variable: unemployment reduction.

b. Predictors: (Constant), infrastructural development.

Source: Field Survey, 2021.

The coefficient table below shows that the $\mathrm{t}$ value is 9.060 while the sig value is .000 which is lesser than the probability level of .05 . This reveals that there is significant of the independent variable over the dependent variable.

Table 7c. Cooefficient

\begin{tabular}{|c|c|c|c|c|c|c|}
\hline \multicolumn{7}{|c|}{ Coefficients $^{\mathrm{a}}$} \\
\hline \multirow[t]{2}{*}{ Model } & & \multicolumn{2}{|c|}{ Unstandardized Coefficients } & $\begin{array}{l}\text { Standardized } \\
\text { Coefficients }\end{array}$ & \multirow[t]{2}{*}{$\mathrm{t}$} & \multirow[t]{2}{*}{ Sig. } \\
\hline & & $\mathrm{B}$ & Std. Error & Beta & & \\
\hline \multirow{2}{*}{1} & (Constant) & 9.385 & 1.036 & & 9.060 & .000 \\
\hline & insufficient finance & .037 & .116 & .034 & .324 & .747 \\
\hline
\end{tabular}

a. Dependent Variable: small business growth and survival.

Source: Field Survey, 2021.

\section{Discussion and Conclusion}

\subsection{Discussion of Findings}

Unemployment among Nigerian graduates has weakened the national economy as individuals are unable to contribute to the economy. Nigeria has a history of economic stagnation that has led to decline in white collar jobs. The inclusion of entrepreneurial course in all disciplines will to a great extent, assist in solving this problems of high unemployment and underemployment. Entrepreneurial education in this paper has been recognized as a catalyst to speed up the employment opportunities as this will exposed and encouraged graduates to start up businesses and improve business potentials among graduates. An effective strategy to develop the indigenous private sector and reduce unemployment among Nigerian graduates is through entrepreneurial education 
The inferential statistical data analysis provided evidence of existing relationships amongst the variables.

\subsection{Conclusion}

Based on the above findings and analyses it will be instructive to conclude skill acquisition has significant effect on unemployment reduction. Entrepreneurship empowerment affects reduction of unemployment. Infrastructural development has significant effect on unemployment reduction in Anambra state and Nigeria as a whole. To this end, it is recommended that entrepreneurial education in tertiary institutions should be practical oriented rather than theory as this will exposed the students to various lucrative skills. Government should provide a means of getting loans by small scale business owners in order to enhance their economic activities in Nigeria. Private investors can also support small scale business owners towards enhancing their economic activities through improved training and provision of soft loans. Government policies should also put in place that will promote efficiently aid the activities of small businesses in Nigeria.

\section{References}

Adebisi, T. A., \& Oni, C. S. (2012). Assessment of Relevance of National Directorate of Employment Training Programme to the Needs of the Trainees in South-West in Nigeria. International Journal of Vocational and Technical Education, 4(3), 29-37.

Agu, B. O., Anidiobu, G., \& Ezinwa, C. E. (2016). Entrepreneurship Education: A Panacea for Unemployment in Nigeria. NG-Journal of Social Development, 5(2), 1-11. https://doi.org/10.12816/0031164

Antoncic, B., \& Hisrich, R. D. (2003). Clarifying the Intrapreneurship Concept. Journal of Small Business and Enterprise Development, 10(1), 7-24. https://doi.org/10.1108/14626000310461187

Asogwa, O. S., \& Dim, E.-M. (2016). Entrepreneurship Development And Unemployment Reduction In Nigeria. International Journal of Business and Management Review, 4(8), 27-43.

Babalola, J. B. (2007). Reinventing Nigerian Higher Education for Youth Employment in a Competitive Global Economy. A lecture delivered at University of Calabar, Department of Educational Administration and Planning, University of Calabar.

Ekpo, P. (2010). An Evaluation of Graduate Unemployment Among University Students in Nigeria. Daily Independent, February 7, p 10.

Gibson, A. (2001). Business Development Services-Core Principles and Future Challenges. London: Small Enterprises Development.

Ezeanokwasa, F. N., \& Nwachukwu, O. P. (2014). effective entrepreneurship skills in reducing unemployment through small business innovation in Nigeria. Information and Knowledge Management, 4(11), 96-110.

Maina, S. (2013). The Role of Entrepreneurship Education on Job Creation among Youths in Nigeria. International $\begin{array}{llllll}\text { Letters of Social } & \text { Humanistic }\end{array}$ https://doi.org/10.18052/www.scipress.com/ILSHS.15.87

Muogbo Uju, S., \& John-Akamelu, C. R. (2018). Impact of Entrepreneurial Skills in Reducing Youth Unemployment in Nigeria European. Journal of Business, Economics and Accountancy, 6(3), 34-55.

Nwachukwu, I. (2012). Nigeria's Unemployment Rate at 23.9\% in 2011. Retrieved August 20, 2017, from http://business day on line.com/NG/index.phb/economic

Olaniyan, D. A., \& Okemakinde, T. (2008). Human Capital Theory: Implications for Educational Development. European Journal of Scientific Research, 24(2), 157-162.

Olubukola, S. A. (2013). Unemployment and Security Challenges in Nigeria. International Journal of Humanities and Social Sciences, 3(7), 146-156.

Robert, B. (1991) Ec onomic Growth in a Cross Section of Countr ies. Quarterly Journal of Economic, 106(2) 407-414. https://doi.org/10.2307/2937943

Tambari, D. M., \& Popnwin, B. M. (2017). The role of entrepreneurial education in the reduction of unemployment among Nigerian graduates. International Journal of Scientific \& Engineering Research, 8(11), 234-246.

Van-Den-Berg, H. (2001). Economic Growth and Development (International Edition). NewYork: Mc Graw Hill Companies. Inc. 


\section{Copyrights}

Copyright for this article is retained by the author(s), with first publication rights granted to the journal.

This is an open-access article distributed under the terms and conditions of the Creative Commons Attribution license (http://creativecommons.org/licenses/by/4.0/). 